
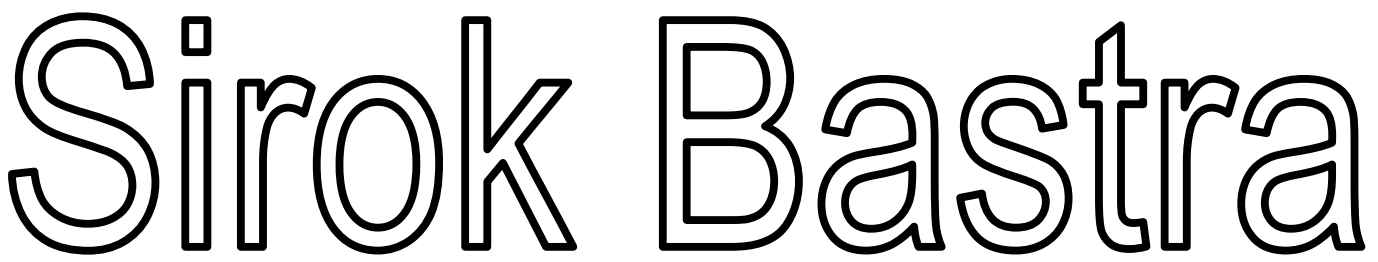

JURNAL ILMIAH KEBAHASAAN DAN KESASTRAAN

\begin{tabular}{|c|c|c|c|c|c|}
\hline $\begin{array}{c}\text { Sirok Bastra } \\
\text { Jurnal Kebahasaan dan } \\
\text { Kesastraan }\end{array}$ & Volume 2 & Nomor 2 & $\begin{array}{c}\text { Hlm. } \\
121-210\end{array}$ & $\begin{array}{l}\text { Pangkalpinang, } \\
\text { Desember 2014 }\end{array}$ & $\begin{array}{c}\text { ISSN } \\
2354-7200\end{array}$ \\
\hline
\end{tabular}

KANTOR BAHASA PROVINSI BANGKA BELITUNG 


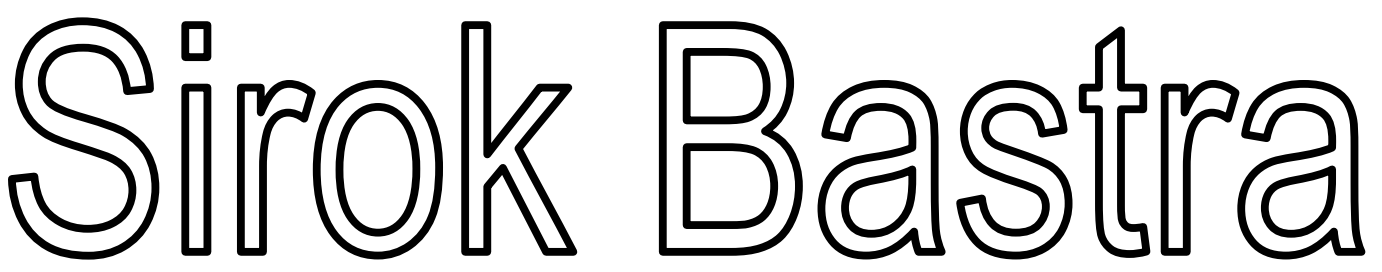

JURNAL ILMIAH KEBAHASAAN DAN KESASTRAAN

Jurnal ini merupakan wadah informasi mengenai kebahasan, kesastraan, dan pengajarannya yang memuat hasil penelitian, studi kepustakaan, dan tulisan ilmiah bidang kebahasan dan kesastraan serta pengajarannya. Sirok Bastra terbit dua kali setahun, yakni Juni dan Desember, serta terbit sejak Juni 2013.

\section{Penanggung Jawab}

Kepala Kantor Bahasa Provinsi Bangka Belitung Drs. Umar Solikhan, M.Hum.

Mitra Bestari

Prof. Dr. Agus Nuryatin, M.Hum. (Bidang Sastra dan Pengajarannya)

Prof. Amrin Saragih, Ph.D., M.A. (Bidang Bahasa dan Pengajarannya)

Dr. Felicia Nuradi Utorodewo, M.Hum. (Bidang Bahasa dan Pengajarannya)

Dr. Pujiharto, M.Hum. (Bidang Sastra dan Pengajarannya)

\section{Pemimpin Redaksi}

Rahmat Muhidin, S.S.

\section{Penyunting}

Prima Hariyanto, S.Hum.

\section{Perancang Sampul}

Feri Pristiawan, S.S.

\section{Kesekretariatan}

Khaliffitriansyah, S.Pd.

Dea Letriana Cesaria, S.Hum.

Lia Aprilina, S.Pd.

Andrian Priyatno, A.Md.

Elzam

\section{Alamat Redaksi dan Penerbit}

Kantor Bahasa Provinsi Bangka Belitung

Ruko Permata 7, Jalan Solihin G.P. Km 4, Kota Pangkalpinang, Prov. Kepulauan Bangka Belitung

Telp./Faks.: 0717-438455, Pos-el: sirokbastra@gmail.com, sirokbastra@kemdikbud.go.id

Pemuatan suatu tulisan dalam jurnal ini tidak berarti redaksi menyetujui isi tulisan tersebut. Isi tulisan menjadi tanggung jawab penulis. Tulisan telah ditinjau dan diulas oleh mitra bestari. Setiap karangan dalam jurnal ini dapat diperbanyak setelah mendapat izin tertulis dari penulis, redaksi, dan penerbit. 


\section{PENGANTAR}

Puji syukur ke hadirat Pemilik dan Pencipta semesta ini yang memiliki kuasa atas diri-Nya sendiri. Dialah Tuhan Yang Maha Esa yang telah memberikan rahmat dan hidayah-Nya sehingga Volume 2 Nomor 2 Jurnal Sirok Bastra Tahun 2014 dapat terbit tepat pada waktunya.

Pada edisi ini, dimuat sepuluh tulisan, yakni satu tulisan kebahasaan, satu tulisan pengajaran bahasa, dan delapan tulisan kesastraan. Dalam penelitiannya, Anitawati Bachtiar, Adek Dwi Oktaviantina, dan Rukmini membahas penggunaan alih kode dan campur kode pada dialog ubrug. Berdasarkan penelitian, ditemukan bentuk alih kode intern, berupa peralihan dari bahasa Jawa Serang menjadi Sunda Banten dan sebaliknya, serta alih kode metaforis dan situasional. Terdapat pula campur kode ke dalam yang berbentuk penyisipan kata pada kalimat yang diucapkan para pemain. Tujuan penggunaan alih kode dan campur kode itu adalah untuk memecah kekakuan saat pementasan, serta membangkitkan rasa humor agar penonton dapat terhibur.

Abdul Aziz melakukan penelitian yang bertujuan untuk mengupayakan peningkatan keterampilan siswa dalam menulis paragraf melalui metode inkuiri dengan menggunakan media audio pada siswa kelas $\mathrm{X}_{1}$ SMA DDI Alliritengae, Kabupaten Maros. Hasil penelitian menunjukkan bahwa metode inkuiri dengan menggunakan media audio dapat meningkatkan kemampuan menulis paragraf siswa kelas $\mathrm{X}_{1}$ SMA DDI Alliritengae, Kabupaten Maros pada tahap pelaksanaan dan tahap penilaian.

Dalam kajiannya, Tri Lia memaparkan nilai sosial dan budaya dalam cerita pendek "Sri Sumarah" karya Umar Kayam. Berdasarkan analisis, ditemukan beberapa nilai sosial budaya yang terdapat dalam cerita pendek ini, yaitu wayang dan stratifikasi sosial, masyarakat Jawa yang nrimo, sistem sapaan dalam masyarakat Jawa, mistik kejawen, masyarakat Jawa yang pembalas budi, keselarasan hidup masyarakat Jawa, dan latar politik PKI.

Dalam kajiannya, Dindin Samsudin membandingkan teka-teki (pertanyaan tradisional) yang terdapat di Provinsi Nanggroe Aceh Darussalam, yakni hiem dan yang terdapat di Provinsi Jawa Barat, yakni tatarucingan. Berdasarkan penelitian, terdapat beberapa hiem Aceh dan tatarucingan Sunda yang memiliki persamaan.

Dalam kajiannya, Kurniati membahas novel Orang-Orang Proyek karya Ahmad Tohari yang menurutnya berusaha menghadirkan sebuah realitas kemanusiaan, yakni melawan korupsi dan berbagai penyimpangan. Penulis menunjukkan bahwa di dalam novel tersebut terdapat kebenaran sosial. Karya ini memiliki sebab dan hasil kehebatan nilai artistik sebuah karya sastra (dengan dokumen sosialnya) sebagai potret kenyataan sosial.

Dalam penelitiannya, Sony Sukmawan membahas apokaliptisme sastra lisan Lereng Arjuna. Ciri-ciri yang terdapat dalam sastra lisan Lereng Arjuna dalam wujud (i) pemahlawanan tokoh mitologis dan sosok cikal bakal, trindih ukir, atau babat alas desa setempat; (ii) implikasi gagasan apokaliptik di balik latar penamaan desa, latar penamaan situs-situs purbakala, dan situs keramat alami; (iii) penamaan para-baureksa dalam mantra; serta (iv) pengungkapan apokaliptik sebagai pemulihan stabilitas alam melalui tindakan pencegahan yang persuasif.

Hestiyana membahas tema dan amanat cerita rakyat di Kecamatan Karang Intan, Kabupaten Banjar. Dalam penelitiannya, ditemukan tiga bentuk cerita rakyat, yaitu dongeng, legenda, dan mite. Cerita rakyat tersebut terdiri atas satu dongeng yang berjudul "Ular Tadung di Gunung Kiyau"; dua legenda berjudul "Asal Usul Nama Desa Karang Intan" dan "Asal Usul Nama Danau Purun"; dan satu mite berjudul "Pamandian Putri di Gunung Putra Bulu".

Dalam penelitiannya, Helmina Kastanya membahas tradisi lisan tatabuang manare dan badendang yang merupakan salah satu kekayaan sastra yang mengandung nilai estetika dalam pesta pernikahan masyarakat Pulau Ambon. Berdasarkan penelitian, bentuk tradisi lisan tatabuang manare dan badendang adalah prosesi berbalas pantun sambil menari diiringi alunan musik totobuang dan tifa. Tradisi ini berfungsi sebagai media penyatuan dua keluarga yang baru menjadi besan. Adapun nilai yang terkandung di dalamnya adalah nilai percintaan, kekeluargaan, dan sosial.

Dalam penelitiannya, Bagus Kurniawan membahas strategi pembacaan dekonstruksi karakter Arjuna sebagai lelananging jagad dalam lakon-lakon wayang purwa. Menurutnya, pemaknaan terhadap wayang masa kini mulai beragam, tidak hanya melalui dikotomi hitam-putih, tetapi juga melalui berbagai tafsir yang kemudian 
mendekonstruksi makna yang sudah mapan. Dalam tulisan ini, diuraikan strategi pembacaan secara dekonstruksi terhadap karakter Arjuna dengan menggunakan beberapa lakon wayang berbahasa Indonesia yang diterbitkan di majalah Cempala.

Mulawati mengkaji nilai karakter bangsa dalam nyanyian rakyat Muna di Provinsi Sulawesi Tenggara. Berdasarkan penelitian, unsur intrinsik nyanyian rakyat Muna menyiratkan nilai-nilai karakter bangsa seperti disiplin, selalu bekerja keras, mandiri, kreatif, dan toleransi.

Kami mengucapkan terima kasih kepada para penulis yang telah bersedia menerbitkan karya mereka pada edisi ini. Para penulis merupakan peneliti, pakar, dosen, guru, dan mahasiswa dari berbagai sekolah, perguruan tinggi, dan instansi. Terima kasih juga kami sampaikan kepada para mitra bestari yang telah memberi ulasan terhadap tulisan-tulisan yang masuk ke redaksi.

Demi memenuhi keberagaman isi dan penulis, Sirok Bastra membuka kesempatan bagi para peneliti dan penulis untuk menyampaikan hasil penelitian dan pemikiran mutakhir dalam bidang kebahasaan, kesastraan, dan pengajarannya.

Pangkalpinang, Desember 2014

\section{Tim Redaksi}




\section{UCAPAN TERIMA KASIH UNTUK MITRA BESTARI}

Redaksi Sirok Bastra mengucapkan terima kasih kepada para mitra bestari yang telah meninjau, menimbang, dan mengulas makalah-makalah yang diterbitkan dalam Sirok Bastra Volume 2 Nomor 2, edisi Desember 2014, yakni

\section{Prof. Dr. Agus Nuryatin, M.Hum.}

Bidang Sastra dan Pengajarannya

Universitas Negeri Semarang

Semarang, Jawa Tengah

Prof. Amrin Saragih, Ph.D., M.A.

Bidang Bahasa dan Pengajarannya

Universitas Negeri Medan

Medan, Sumatra Utara

\section{Dr. Felicia Nuradi Utorodewo, M.Hum.}

Bidang Bahasa dan Pengajarannya

Universitas Indonesia

Depok, Jawa Barat

\section{Dr. Pujiharto, M.Hum.}

Bidang Sastra dan Pengajarannya

Universitas Gadjah Mada

Yogyakarta, Daerah Istimewa Yogyakarta 


\section{DAFTAR ISI}

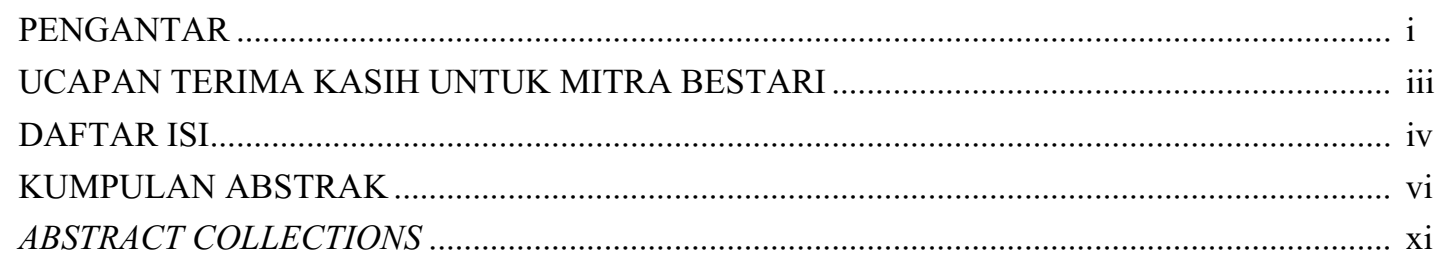

\section{UBRUG: KAJIAN SOSIOLINGUISTIK}

(Ubrug: Sociolinguistic Study)

Anitawati Bachtiar, Adek Dwi Oktaviantina, dan Rukmini $121-128$

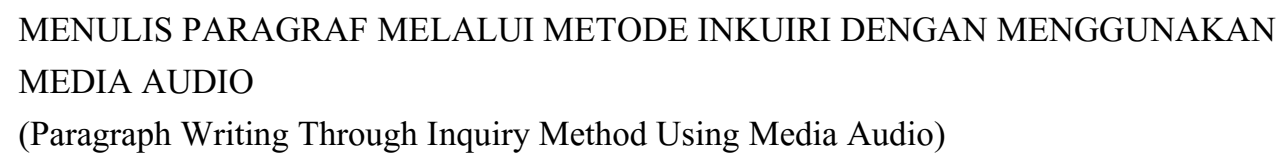

TEMA DAN AMANAT CERITA RAKYAT DI KECAMATAN KARANG INTAN, KABUPATEN BANJAR

(Theme and Message of Folklore in Karang Intan Subdistrict, Banjar Regency)

TATABUANG MANARE DAN BADENDANG DALAM PESTA PERNIKAHAN MASYARAKAT PULAU AMBON

(Tatabuang Manare and Badendang in Wedding Party of Ambon Island Society) 
MENGGUGAT ARJUNA SEBAGAI LELANANGING JAGAD: SEBUAH STRATEGI PEMBACAAN DEKONSTRUKSI KARAKTER ARJUNA DALAM LAKON-LAKON WAYANG PURWA

(Arjuna Sued as A Man of Universe: The Deconstruction of Reading Strategy for Arjuna's Character on Purwa Puppet Shows)

Bagus Kurniawan $193-200$

NILAI KARAKTER BANGSA DALAM NYANYIAN RAKYAT MUNA

(Nation Character Values in Munanese Folksong)

Mulawati $201-201$ 
Sony Sukmawan : Apokaliptisme Sastra Lisan Lereng Arjuna

\title{
APOKALIPTISME SASTRA LISAN LERENG ARJUNA
}

The Apocalyptic of Arjuna Slopes Oral Literature

\author{
Sony Sukmawan \\ Pendidikan Bahasa dan Sastra Indonesia, Fakultas Ilmu Budaya, Universitas Brawijaya \\ Jalan Veteran, Malang, Jawa Timur 65145 \\ Pos-el: swara_sukma_lelaki@yahoo.co.id
}

(diterima 13 Oktober 2014, disetujui 3 November 2014, revisi terakhir 1 Desember 2014)

\begin{abstract}
Abstrak
Sastra apokaliptik adalah jenis sastra naratif yang (i) mengisahkan wahyu yang dimediasi oleh makhluk dari dunia yang diterimakan kepada manusia; (ii) mengungkapkan suatu realitas transenden yang temporal; (iii) menyangkut bayangan eskatologis keselamatan. Ciri-ciri yang terdapat dalam sastra lisan Lereng Arjuna dalam wujud (i) pemahlawanan tokoh mitologis (Semar dan Dewi Sri) dan sosok cikal bakal, trindih ukir, atau babat alas desa setempat; (ii) implikasi gagasan apokaliptik di balik latar penamaan desa, latar penamaan situs-situs purbakala dan situs keramat alami; (iii) penamaan para-baureksa dalam mantra, yang diangkat atau terinspirasi dari penggalan, kutipan, atau sebagian kisah pewayangan, suluk, dan kitab suci; serta (iv) pengungkapan apokaliptik sebagai pemulihan stabilitas alam melalui tindakan pencegahan yang persuasif (melalui pemujaan mantra, laku ritual), bukan mengubah masa depan alam.
\end{abstract}

Kata Kunci: apokaliptik, sastra lisan, masyarakat Lereng Arjuna

\begin{abstract}
Apocalyptic literature is a genre of narrative that tells the story of revelation which is mediated by the creatures of the world that were administered to humans, (ii) disclose a transcendent reality which is temporal; (iii) regarding the shadow eschatological salvation. Characteristics contained in the oral literature in the form of Arjuna Slope (i) pemahlawanan mythological figures (Semar and Dewi Sri) and the origin of ba-cal figure, trindih carving, or tripe local village, (ii) the implications of the idea behind the apocalyptic background of naming the village , background naming archaeological sites and natural sacred sites, (iii) the naming of the baureksa mantra, which lifted or inspired from fragments, quotes, or wayang story part, mysticism, and scripture, and (iv) disclosure of apocalyptic as the restoration of stability precautions nature through persuasive (through worship spell, ritual behavior), instead of changing the future of nature.
\end{abstract}

Keywords: apocalyptic, oral literature, the slope of Arjuna

\section{PENDAHULUAN}

\subsection{Latar Belakang}

Sastra apokaliptik adalah genre sastra naratif tentang (i) wahyu yang dimediasi oleh makhluk dari dunia yang diterimakan kepada manusia; (ii) mengungkapkan suatu realitas transenden yang temporal; (iii) menyangkut bayangan eskatologis keselamatan, (iv) bersifat spasial; dan (v) melibatkan dunia supranatural yang lainnya (Wolf dalam Carter, 2007:3). Beberapa karakteristik yang umum dalam sastra apokaliptik adalah (i) penulis cenderung memilih beberapa orang besar pada masa lalu dan membuatnya menjadi pahlawan dalam cerita; (ii) pahlawan sering mengalami suatu perjalanan, disertai oleh pemandu surgawi yang menunjukkan padanya pemandangan yang menarik dan memberikan komentarnya; (iii) informasi sering dikomunikasikan melalui visi; (iv) visi sering menggunakan simbolisme yang aneh, bahkan penuh teka-teki; (v) visi sering bersifat pesimis sehubungan dengan kemungkinan bahwa intervensi manusia akan memperbaiki situasi saat ini; (vi) visi biasanya berakhir dengan Tuhan yang membawa ke kehancuran dahsyat akhir dan membangun situasi yang lebih baik; (vii) penulis apokaliptik sering menggunakan nama samaran, mengklaim bahwa dia menulis demi pahlawan yang dipilihnya; (viii) penulis sering mengambil sejarah masa lalu dan 
menuliskannya kembali seolah-olah itu ramalan; dan (ix) fokus apokaliptik adalah menghibur dan mempertahankan "sang pembela kebenaran" (Morris dalam Carter, 2007:4).

Wacana apokaliptik sesungguhnya telah digambarkan dalam beberapa karya sastra Jawa, di antaranya dapat ditemukan dalam Jangka Jayabaya dan Serat Kalatidha, yang keduanya disampaikan oleh Raden Ngabehi Ranggawarsita. Kutipannya sebagai berikut.

Tandane zaman kalabendu: lindu ping pitu sedina, lemah bengkah, manungsa pating galuruh, akeh kang nandang lara, pagebluk rupa-rupa, mung setitik sing mari akeh-akehe pada mati. Zaman kalabendu iku wiwit yen wis ana kreta mlaku tanpa jaran; tanah Jawa kalungan wesi, prau mlaku ing nduwur awang-awang, kali ilang kedunge, pasar ilang kumandange, akeh udan salah mangsa. Zaman iku bakal sirna lan gantine yoiku zaman Ratu Adil, zaman kamulyan.

Terjemahan

Tanda zaman kehancuran: gempa bumi terjadi tujuh kali dalam sehari, tanah retak; manusia dalam kekacauan dan keributan; banyak yang ditimpa sakit; wabah penyakit bermacam-macam, hanya sedikit yang sembuh, kebanyakan meninggal. Zaman ini dimulai jika sudah ada kereta yang dapat berjalan tanpa kuda (mobil, kereta api); tanah Jawa dikelilingi besi (rel kereta api); perahu berjalan di atas awan (pesawat udara); sungai menjadi dangkal; pasar sepi (tergeser mal-mal); sering terjadi hujan salah musim. Zaman itu akan berakhir dan diganti dengan zaman Ratu Adil, zaman kemuliaan.

Visi atau ramalan tentang akhir dunia sebagai salah satu penanda penting teks apokaliptik termuat dalam penggalan di atas. Lindu ping pitu sedina, lemah-lemah bengkah, kali ilang kedunge, dan akeh udan salah mangsa menjadi tanda-tanda perubahan alam (material/fisik) yang mengarah kepada kerusakan dan kehancuran. Demikian pula dalam Serat Kalatidha (secara harafiah kalatidha berarti 'zaman edan'), tanda-tanda akhir zaman (apokaliptik) juga digambarkan dengan rinci. Pada bait ke-11 dalam metrum sinom ditegaskan "Ya Allah ya Rasulullah, Kang sipat murah lan asih, mugi-mugia paringa pitulung ingkang martani ing alam awal akhir" 'Ya Allah ya Rasulullah, yang Pemurah dan Pengasih, mudah-mudahan memberi pertolongan berupa kesabaran (marta, sareh) kepada hambamu, di saat-saat menjelang akhir ini.

\subsection{Masalah}

Teks sastra kearifan lingkungan sastra Lereng Arjuna dibangun dan dibentuk oleh unsur sastra, ekologi, dan unsur nilai budaya. Meskipun ketiga unsur tersebut diacu dalam pembahasan, unsur sastra tetap menjadi pijakan awal dalam kajian ini. Atas dasar itu, kajian ini difokuskan kepada matra (dimensi) sastra (lingkungan) dalam sastra lisan masyarakat Lereng Arjuna, khususnya narasi dan puitika apokaliptik dalam sastra lisan masyarakat Lereng Arjuna.

Bahasan matra sastra akan menghasilkan konstruksi puitik dan naratif sastra lingkungan. Unsur penting (utama) dalam konstruksi puitik dan naratif sastra lingkungan atau sastra ekologi adalah (i) hadirnya lingkungan/alam dan tema tentangnya dan (ii) menjadikan tema lingkungan sebagai orientasi etis teks.

\subsection{Tujuan}

Secara umum, kajian ini dapat mendokumentasikan, menginventarisasikan, melestarikan, memperkenalkan, merevitalisasikan, dan memopulerkan kembali sastra lisan Jawa dengan beragam fungsi dan potensinya, terutama muatan kearifan lokal yang bermanfaat bagi pemeliharaan, pelestarian, dan pemulihan sumber daya alam. Dapat dikatakan bahwa upaya pengumpulan, pemeliharaan, dan pengembangan sastra lisan simetris dengan upaya penghimpunan, pemberdayaan, dan aktualisasi nilainilai kearifan lingkungan dalam konteks yang lebih luas. Secara khusus, kajian ini dapat merumuskan konstruksi puitik dan naratif sastra (lisan) apokaliptik. Rumusan ini akan menjadi salah satu dasar dalam membangun struktur puitik dan naratif sastra lingkungan/sastra ekologi yang berbasis kultur lokal Nusantara.

\subsection{Metode Penelitian}

Orientasi teoretik ekokritik sastra digunakan dalam penelitian ini. Dalam memandang data, penelitian ini menggunakan pendekatan interdisipliner, yakni pendekatan ekokritik sastra yang ditopang dan ditunjang oleh pendekatan budaya, etika lingkungan, dan sastra lisan. Pendekatan 
ekokritik sastra digunakan karena sastra lisan Lereng Arjuna bermatra sastra dan berorientasi ekologis. Pendekatan budaya digunakan karena sastra lisan Lereng Arjuna bermatra nilai budaya. Sementara itu, teori etika lingkungan dimanfaatkan karena sastra lisan Lereng Arjuna bermatra alam/lingkungan. Adapun teori sastra lisan digunakan karena sastra lisan Lereng Arjuna bermatra kelisanan.

Kajian ekokritik sastra dapat (1) mengonstruksi struktur puitik dan naratif sastra kearifan lingkungan, (2) melacak ide/gagasan tentang lingkungan dan representasinya dalam sastra lisan, serta (3) menghasilkan paparan tentang muatan nilai budaya dalam sastra lisan

Lereng Arjuna berkaitan dengan nilai kearifan lingkungan dan relevansinya dalam konteks kebudayaan yang lebih luas dan mendalam. Secara kontekstual, kajian ini juga dapat mengungkapkan praksis sikap, pandangan, penilaian, dan perilaku sosio-kultural serta religio-kultural masyarakat dalam relasinya dengan lingkungan atau alamnya.

Prosedur etnografis juga digunakan dalam pengumpulan dan pemaknaan data dengan pertimbangan bahwa penelitian ini bertujuan mendeskripsikan secara mendalam dan holistik keterkaitan alam dengan kebudayaan masyarakat Lereng Arjuna (sebagai hasil dan proses) sebagaimana adanya (senyatanya). Prosedur ini dilakukan melalui penyajian pandangan hidup masyarakatnya, bagaimana mereka berpikir, hidup, berperilaku, berinteraksi dan bekerja sama dalam konteks ekologi (emik) melalui fenomena teramati dalam kehidupan sehari-hari (bandingkan dengan Spradley, 1997:5).

Dengan demikian, akan ditemukan makna tindakan budaya masyarakat Lereng Arjuna terhadap lingkungannya yang diekspresikan melalui apa saja, termasuk melalui sastra lisan mereka (Endraswara, 2010). Oleh karena itu, peneliti menjadi instrumen paling penting dalam pengumpulan dan penafsiran data (Sudikan, 2001:85-86).

\section{KAJIAN TEORI}

\subsection{Ekokritik Sastra, Sastra Lingkungan, dan Sastra Apokaliptik}

Ekokritik sastra merupakan teori kritis dalam pendekatan mutakhir sastra. Finnegan (1992:167) mengungkapkan bahwa teks oral (termasuk sastra lisan) dapat dianalisis dengan pendekatan populer, di antaranya pendekatan pascastruktural, feminisme, dekonstruksi, dan teori kritis. Ekokritik adalah studi mengenai hubungan sastra dan lingkungan fisik (Glotfelty, 1996x:ix). Penggunaan ekokritik dalam telaah sastra lisan dikatakan tepat mengingat sastra lisan, yang berhabitat di dalam peradaban tradisionallisan, berpotensi besar mengungkapkan nilai-nilai kearifan terhadap alam. Garrard (2004:4) menyebutkan bahwa ekokritik dapat membantu menentukan, mengeksplorasi, dan bahkan menyelesaikan masalah ekologi dalam pengertian yang lebih luas.

Dalam posisinya sebagai karya sastra, sastra lisan masyarakat Lereng Arjuna, dengan seperangkat karakteristik dan muatan kesastraannya, merupakan objek potensial kritik sastra. Dalam fungsinya sebagai media representasi sikap, pandangan, dan tanggapan masyarakat terhadap lingkungan sekitarnya, sastra lisan Lereng Arjuna berpotensi mengungkapkan gagasan tentang lingkungan, termasuk nilai-nilai kearifan lingkungan. Hal ini sangat beralasan mengingat sastra lisan Lereng Arjuna tumbuh, berkembang, dan bersumber dari lingkungan masyarakat sekitar Lereng Gunung Arjuna. Kerridge (1998) mengungkapkan bahwa ekokritik dapat melacak gagasan tentang lingkungan dan representasinya.

Sebagai sastra lingkungan, sastra lisan Leren Arjuna memiliki ciri apokaliptik. Sastra apokaliptik berbentuk sebuah wahyu tentang akhir sejarah. Tema dasar sastra apokaliptik biasanya berupa sebuah perjuangan antara yang baik dan jahat. Apokaliptisisme digambarkan sebagai genre yang lahir dari sebuah krisis, yang dirancang untuk memperkuat tekad dari komunitas yang terpinggirkan dengan memberikan harapan dan visi kebebasan dari keterbelengguannya (Thompson, 1997:13-14).

\subsection{Sastra Lisan Jawa}

Sastra lisan adalah kesusastraan yang mencakupi ekspresi kesusastraan warga suatu kebudayaan yang penyampaian dan penyebarannya dilakukan dan diturun(-temurun)kan secara lisan (dari mulut ke mulut) (Hutomo, 1991:1; Tonkin, 2000:719). Sutarto (2009:2 - 5) memandang bahwa sastra lisan dalam 
banyak aspek memiliki kesamaan dengan tradisi lisan. Sebagai produk peradaban lisan, sastra lisan dilandasi oleh (1) pemikiran lisan (oral thought) dengan karakteristik konservatif, agonistik, homeostatik, empatik-partisipatoris, dan situasional; (2) diekspresikan secara lisan (oral expression) dengan ciri penggunaan pola formulaik, aditif, agregatif, dan redundan-kopius; dan (3) terwujud dalam bentuk naratif lisan (oral narrative) dengan ciri umum berupa penggunaan alur episodik, tokoh datar, dan mengandung ajaran moral.

Sastra lisan merupakan bagian dari folklor. Berdasarkan klasifikasi folklor, sastra lisan dapat dikelompokkan dalam folklor lisan dan sebagian lisan (Danandjaya, 1984:21-22). Sastra lisan kelompok pertama adalah sastra lisan yang penyampaiannya dengan mulut (lisan) saja; sedangkan kelompok yang kedua merupakan campuran penyampaian lisan dan bukan lisan, yakni gabungan seni kata, suara, gerak, musik, rupa, dan pertunjukan (Finnegan, 1979:28).

Beberapa fungsi yang dimiliki sastra lisan yaitu (1) sebagai sistem proyeksi; (2) pengesahan kebudayaan; (3) sebagai alat pemaksa berlakunya norma-norma sosial dan sebagai alat kontrol sosial; serta (4) sebagai alat pendidikan (Bascom dalam Dundes, 1965:279-298). Sebagai bagian dari folklor, sastra lisan mengimplikasikan dua agen yang berbeda (performer dan listener) yang saling berhadapan, terkadang tanpa mediasi.

Sastra lisan terus berubah secara ajeg dan karena keajegan perubahan ini, ia tidak bisa dipelajari secara mendalam jika hanya direkam sekali. Propp (1997:8 - 9) menyebutkan bahwa hasil rekaman tersebut adalah varian. Varian-varian ini bisa ditututurkan secara berbeda oleh orang (performer) yang sama, lebih-lebih dituturkan oleh orang yang berbeda. Dalam kerangka sejarah, folklor tidak diciptakan oleh siapa pun dan muncul pada masa prasejarah dalam wadah suatu ritual atau cara tertentu yang bertahan melalui transmisi oral hingga saat ini. Folklor yang demikian disebut folklor murni (pure folklore).

Sastra lisan memiliki karakter yang berbeda dengan sastra tulis. Nilai-nilai yang dikandung dalam sastra lisan lebih kompleks dan tidak dimiliki oleh sastra tulis. Sastra lisan merupakan arus atas (upper stream). Arus atas itu dipengaruhi oleh arus bawah (low stream) yang sangat kuat. Arus bawah itu berupa sistem nilai budaya dalam masyarakat. Sistem nilai budaya itu berfungsi sebagai pedoman tertinggi bagi kelakuan manusia. Nilai budaya merupakan nilai atas dalam wujud ideal kebudayaan karena paling berpengaruh dalam memotivasi orang untuk melakukan atau tidak melakukan sesuatu (Anwar, 2001:4).

Propp (1997:7—8) menuturkan bahwa sastra (tulis) ditransmisikan melalui tulisan dan berbentuk tetap (tidak berubah), sedangkan folklor (sastra lisan) ditransmisikan melalui mulut ke mulut, bersirkulasi dan berubah setiap saat.

Sastra lisan menggambarkan kehidupan masyarakat. Sastra lisan Jawa, misalnya, akan menggambarkan kehidupan masyarakat dengan latar sosial priyayi atau wong cilik dan dapat pula menggambarkan latar kultural santri atau abangan. Lapis sosiokulutral kehidupan apa pun yang digambarkannya, sastra lisan Jawa senantiasa dibingkai oleh kerangka kebudayaan Jawa dengan nilai-nilai ke-Jawa-annya. Dalam nilai-nilai tersebut, termuat kearifan sebagai wujud kecerdasan masyarakat Jawa yang diperoleh melalui pengalaman hidup serta terwujud dalam ciri-ciri kebudayaan. Dengan demikian, nilai-nilai kearifan (lokal) budaya Jawa dalam sastra lisan merupakan wujud kecerdasan yang dihasilkan oleh pengalaman hidup masyarakat Jawa.

Secara lebih khusus, pengalaman hidup masyarakat Jawa membentuk wawasan tertentu tentang lingkungan hidup mereka yang disebut sebagai citra lingkungan. Citra lingkungan ini memberi petunjuk tentang apa yang dipikirkan dan diharapkan masyarakat Jawa dari lingkungannya. Citra masyarakat Jawa tentang lingkungan didasari, misalnya, atas pengetahuan mereka tentang lingkungan, pengetahuan tentang flora, fauna, dan lanskap. Pola berpikir inilah yang kemudian membentuk dan melahirkan etika lingkungan atau kearifan lingkungan.

\subsection{Sastra (Lisan) Jawa dan Kearifan Lingkungan}

Putra (2008) menegaskan sebagian kearifan lokal sebenarnya tersimpan dalam bahasa dan sastra (tertulis maupun lisan) di masyarakat. Hal ini berarti 
dengan menganalisis bahasa dan sastra, akan dapat terungkap berbagai kearifan lokal masyarakat tersebut yang kemudian dapat direvitalisasi untuk kepentingan masyarakat itu sendiri.

Kaitan antara manusia, alam, kearifan lokal, dan sastra lisan tampak dalam pernyataan Butterfield (1993:107) bahwa motif dari dialog yang bermakna antara manusia dan alam berakar dari cerita-cerita lisan rakyat. Para pendongeng di seluruh dunia menceritakan ulang kata-kata yang diucapkan oleh angin, api, gunung, pohon, dan hewan, yang menuntun manusia menuju gerbang ilmu pengetahuan dan pemahaman pentingnya kosmik. Lebih lanjut, Theorey (2010:1) menjelaskan bahwa narasi seperti ini menekankan hubungan audiens dengan lanskap yang hidup, termasuk pengenalan terhadap nilai-nilai bahwa kesehatan lanskap akan memengaruhi keberlangsungan hidup manusia dan masa depannya.

Jika mengacu pada sejumlah paparan definisi sebelumnya mengenai kearifan lingkungan, terdapat karakteristik kearifan lingkungan yang menjelaskan jalinan eratnya dengan sastra (lisan). Semali dan Kincheloe (1998) misalnya, mengatakan bahwa pengetahuan ini (kearifan lingkungan) dinyatakan dalam cerita rakyat, mitos, ritual, dan lain-lain. Sementara itu, Kalland (2000:5) menyebutkan adanya koherensi pengetahuan indigenous dalam ritual dan konstruksi simbolik (dalam hal ini adalah karya sastra).

\section{HASIL DAN PEMBAHASAN}

\subsection{Sosio-Religius Masyarakat Lereng Arjuna}

Kawasan Gunung Arjuna meliputi tiga wilayah kabupaten, yaitu Pasuruan, Malang, Mojokerto; dan satu kota, yaitu Batu. Secara administratif, pengelolaan kawasan Arjuna melampaui batas-batas pemerintahan setempat. Secara sosio-kultural, kawasan Lereng Arjuna berpenduduk multietnis. Sebagian besar adalah suku Jawa (Timur) (Etnis Arek) yang di beberapa tempat berdampingan dengan keturunan suku Madura (Pandalungan) yang sudah lebih dari tiga generasi tinggal di Jawa Timur.

Mata pencaharian utama penduduk kawasan ini adalah bertani, berkebun, dan beternak. Budaya agraris masih berakar kuat dalam kehidupan masyarakat kawasan Arjuna. Tiap tahun, dalam bulan
Suro menurut kalender Jawa, warga desa penyangga hutan Arjuna mengadakan selametan bersih desa. Acara ini merupakan wujud ungkapan terima kasih atas sumber alam yang sudah dinikmati, sekaligus harapan bagi keberhasilan panen mendatang. Beragam selametan kecil-kecilan juga masih dilakukan oleh sekumpulan warga lokal pada setiap bulan-bulan, hari-hari, dan momen-momen khusus tertentu, misalnya slametan desa, sumber air, tandur (musim tanam), panen, khitanan, perkawinan, kelahiran, dan kematian.

Kawasan utara Lereng Gunung Arjuna dikelilingi beberapa desa dan satu (rangkaian) tempat situs-situs keramat yang tersebar di sepanjang jalur utara pendakian ke puncak Gunung Arjuna. Desa-desa yang mengitari kawasan utara Lereng Arjuna di antaranya adalah Desa Tambaksari, Kecamatan Purwodadi; Desa Jatiarjo, Kecamatan Sukorejo, Kabupaten Pasuruan; dan Desa Toyomarto, Kecamatan Singosari, Kabupaten Malang.

Serangkaian situs keramat Lereng Arjuna yang bertebaran di sepanjang jalur utara pendakian Lereng Arjuna adalah Pertapaan Betara Guru, Goa Antaboga, Patuk Watu Kursi, Kompleks Tampuono, Sendang Dewi Kunti, Patung Eyang Semar, Candi Makuta Rama, dan Candi Sepilar.

Secara religio-kultural, masyarakat Desa Tambaksari umumnya adalah pemeluk agama IslamJawa yang lebih condong menjalankan kepercayaan kejawennya dalam kehidupan sehari-hari. Spiritualitas-monisme menjiwai setiap aktivitas masyarakatnya yang bertalian dengan lingkungan mereka. Sebagian masyarakatnya yang lain merupakan penganut Islam Sarengat (Syariat). Hal ini berbanding terbalik dengan masyarakat Desa Jatiarjo yang cenderung menjalankan ajaran Islam secara taat, (meskipun ada sedikit masyarakat, utamanya golongan tua, tetap menjalankan kepercayaan kejawen secara pasif-konservatif). Hal ini dapat dilihat misalnya pada mereka yang tergabung dalam Paguyuban Estu Tunggal (Pangestu) dengan inti ajaran rinosotebu:rila, narima, temen, budi luhur, di dukuh Nggamoh dan Watuagung.

Kuatnya pengaruh Islam tradisional di Kecamatan Sukorejo menjadikan para penganut Pangestu lebih hati-hati dalam menjalankan kepercayaannya agar tidak terulang konflik horizontal sebagaimana pernah 
terjadi di masa lampau. Lain lagi dengan masyarakat Desa Toyomarto yang secara umum lebih egaliter. Baik golongan masyarakat Islam yang taat, golongan masyarakat Abangan, maupun segelintir penghayat spiritualitas monisme dapat hidup berdampingan.

Desa-desa terdekat dari puncak Arjuna memiliki akses lebih besar untuk berinteraksi dengan lingkungan Arjuna. Sistem pengetahuan dan sistem kepercayaan terhadap lingkungan Arjuna secara lebih asli dan murni dimiliki oleh kelompok masyarakat ini. Oleh karena itu, mereka dapat lebih runtut, lengkap, dan jelas mengungkapkan sejarah alam dan mitologi Gunung Arjuna.

Dalam penelitian terhadap gunung Merapi, Triyoga (2010:56) menjelaskan bahwa masyarakat Wukirasih yang bertempat tinggal lebih jauh di bawah Desa Kawastu dan Korijaya sudah tidak mengenal lagi mitos atau legenda Merapi. Secara umum, desa-desa di Lereng Utara Arjuna berdekatan dengan (bahkan menjadi lokasi) peninggalan situs purbakala dan situs keramat alami. Sebagian besar situs yang tersebar di jalur utara pendakian tersebut berupa punden berundak, patung-patung batu sederhana, makam leluhur, bukit keramat, dan sumber mata air suci. Hingga kini, situs-situs tersebut masih sering dikunjungi oleh para peziarah, khususnya pada waktu-waktu tertentu yang dianggap istimewa, misalnya pada hari Jumat Legi dan pada bulan Sura. Di sekitar lokasi situs purbakala dan situs keramat alami ini, banyak berkembang aneka ragam sastra lisan, misalnya legenda Ratawu Tampuono, Legenda Sepilar, Legenda Makuto Romo, Legenda Patuk Watu Kursi, Legenda Sumberawan, Legenda Tambak Watu, Mitos Betara Guru, Mitos Antaboga, dan sebagainya.

\subsection{Ciri Apokaliptik Sastra Lereng Arjuna}

Sastra lisan masyarakat Lereng Arjuna adalah segala bentuk ekspresi kesusastraan masyarakat Lereng Arjuna yang penyampaian dan penyebarannya dilakukan turun-temurun secara lisan yang berisi dan dihasilkan oleh berbagai peristiwa sosial, kebudayaan, dan peristiwa alam mereka. Peristiwa sosio-ekologis yang menghasilkan sastra Lereng Arjuna adalah kerusakan alam dan bencana alam (apokalips).
Sastra apokaliptik sesungguhnya adalah salah satu jenis sastra kearifan lingkungan dengan ciri khas adanya penarasian sejarah alam; penokohpahlawanan karakter yang bervisi alam; pengangkatan tema lingkungan; dan pemberian pengakuan atas keajaiban alam.

Karakteristik apokaliptik dalam sastra lisan Masyarakat Lereng Arjuna yang akan diuraikan dalam kajian ini terdiri atas karakter pahlawan, lingkungan apokaliptik, dan visi atau ramalan.

\subsubsection{Karakter Pahlawan}

Salah satu karakteristik sastra apokaliptik adalah adanya sosok besar pada masa lampau yang dipahlawankan. Sosok pahlawan dalam cerita ini digambarkan sering mengalami suatu perjalanan, disertai oleh pemandu surgawi yang menunjukkan padanya pemandangan yang menarik dan memberikan komentarnya. Dalam sastra lisan masyarakat Lereng Arjuna, sosok besar yang dipahlawankan adalah Arjuna, sedangkan pemandu atau pendampingnya adalah Eyang Semar dan Bagong. Namun demikian, bukan sosok Arjuna yang dipahlawankan, melainkan Eyang Semar yang sebenarnya hanyalah seorang pemandu, pamong, dan pelayan. Bagi masyarakat Jawa, khususnya masyarakat Lereng Arjuna, tokoh Semar merupakan sosok pahlawan mitologis yang berjasa bagi kehidupan dan penghidupan masyarakat. Jasa Eyang Semar dapat ditelusuri dalam 'Legenda Ratawu Tampuono' berikut ini.

Alkisah, Bagong dan Semar menemani perjalanan Arjuna menuju tempat pertapaan. Saat tiba di sebuah tempat, Arjuna meminta Semar untuk mencarikan air minum sebagai penawar dahaganya. Tanpa dipahami oleh Bagong dan Arjuna, Semar mengambil abu sisa pohon dan semak yang terbakar. Abu dalam genggamannya lantas ditaburkan di sekililingnya. Sejurus kemudian, Semar meminta Bagong menancap-nancapkan sebatang kayu (dalam versi yang lain tongkat Semar) di atas taburan abu tersebut. Tiba-tiba saja dari lubang bekas tancapan kayu tersebut keluar air. Maka begitulah, dengan kesaktiannya, Semar berhasil memunculkan mata air setelah terlebih dahulu nyirat-nyirati awu 'menaburkan' (diakronimkan menjadi Ratawu), hasilnya tamtuana (Tampuono) 'pasti ada' mata airnya. Maka jadilah nama sumber air itu Ratawu Tampuono. 
Selain mata air Gumandar, Ratawu Tampuono merupakan mata air yang selama ini memenuhi kebutuhan sehari-hari masyarakat Lereng Arjuna, dalam hal ini masyarakat Tambak Watu. Ratawu Tampuono dalam legenda di atas dipercayai sebagai salah satu tilas kesaktian Eyang Semar yang hingga saat ini masih dapat dinikmati masyarakat.

Secara konseptual, Ratawu juga dapat ditafsirkan sebagai bentuk sandi: rata awu '(me)rata(kan) abu' dan Tampuono bermakna tampu ana 'ada percik (air)' (Tampu bermakna nyiprat mlebu tumrap banyu udan 'percik air hujan' [Bausastra Jawa, 2001:759]). Dengan demikian, Ratawu Tampuono dapat ditafsirkan menjadi meratakan abu (kemudian, sehingga, agar) ada percikan air. Secara biologis/ekologis, terdapat tiga komponen unsur alam fisik dan dua perilaku kosmis. Tiga komponen alam tersebut adalah abu (disejajarkan dengan tanah kompos), tongkat kayu (disejajarkan dengan benih tanaman), dan air (sumber air/mata air). Dua perilaku kosmis adalah meratakan (menaburkan, menyebarkan [pupuk]) dan menancapkan (menanam [bibit]). Jadi, secara implisit, Ratawu Tampuono merupakan sandi/simbol perilaku ekologis yang dapat menyebabkan atau mengakibatkan muncul dan lestarinya mata air. Dalam tafsir ini, 'kesaktian' Semar lebih dapat dirasionalkan sebagai 'kesaktian' simbolik, yakni 'kesaktian' yang lebih direpresentasikan dalam 'gagasan lingkungannya' dalam setiap perilakunya.

Dalam kisah pewayangan Jawa, Semar memang dianugerahi mustika manik astagina. Anugerah ini membuat Semar mempunyai 8 kelebihan, yaitu tidak pernah lapar, mengantuk, jatuh cinta, bersedih, lelah, sakit, kepanasan, dan tidak pernah kedinginan. Selain sakti, Eyang Semar juga dipahami sebagai sosok pemandu yang setia dan dapat dipercaya. Hal ini tecermin dalam 'Legenda Patung Eyang Semar'

Dikisahkan, Arjuna berhasil mencapai puncak gunung dan segera menjalankan laku tapabrata. Sebelum bertapa, Arjuna meminta Eyang Semar untuk menunggunya di suatu tempat di bawah pertapaan tersebut hingga ia kembali dari pertapaannya. Demikian lama dan setianya Semar menunggu hingga tubuhnya menjadi patung batu. Di tempat tersebut kini dapat ditemukan sebuah patung yang berparas mirip tokoh pewayangan Semar.
Sosok Semar sebagai pamong dalam legenda di atas selaras dengan apa yang digambarkan dalam Naskah Paramayoga bahwa Putra sulung Ismaya yang bernama Batara Wungkuham memiliki anak berbadan bulat bernama Janggan Smarasanta (Semarasanta), atau disingkat Semar. Ia menjadi pengasuh keturunan Batara Guru yang bernama Resi Manumanasa dan berlanjut sampai ke anak-cucunya, yaitu Sakri, Sekutrem, Palasara, Abiyasa, Pandudewanata, dan Arjuna. Selain kesaktian dan kesetiaan, pengabdian tanpa batas Eyang Semar terhadap Arjuna juga menjadi 'nilai tambah' tersendiri sehingga ia lebih disegani dan dikultuskan. Tilas Eyang Semar yang berbentuk patung hingga sekarang masih menjadi tempat suci yang dikeramatkan yang masih dikunjungi masyarakat yang hendak melaksanakan ritual. Saat Selamatan Desa dan Selamatan Sumber Air, tempat tersebut masih dikunjungi dan diberi sesajen. Kekeramatan tempat tersebut sudah lama diyakini masyarakat. Banyak kisah misterius yang terjadi di tempat tersebut yang semakin menambah wingit 'keramat' Patung Eyang Semar.

Patung Eyang Semar sebenarnya tidak "menghendaki” dibangun dan dibungkus dengan kain putih karena pernah terjadi payon 'atap' yang baru dibangun oleh seseorang rubuh sesaat setelah pembuatnya meninggalkan tempat tersebut. Hal ini membuktikan bahwa patung Semar tidak mau diperlakukan seperti itu. Masyarakat juga percaya bahwa tempat tersebut memiliki kekuatan gaib yang besar. Konon, Pak Siring pernah mungel 'berikrar' bahwa jika yang bersangkutan mendapatkan jabatan yang lebih tinggi di tempat kerjanya, ia akan membawakan sesaji nasi tumpeng untuk Eyang Semar. Namun, setelah keinginannya tercapai, yang bersangkutan lupa akan janji tersebut. Akibatnya satu keluarganya tewas mengenaskan dalam kecelakaan lalu lintas di perlintasan kereta api.

Diceritakan pula, Pak Kadirun (Danramil Purwadadi) pernah mungel. Ia menyangsikan kesakralan tempat Patung Eyang Semar. Ia mengatakan bahwa jika tempat ini memang memiliki kekuatan gaib, senapan di tangannya tidak akan meletus jika ditembakkan. Benar saja, hingga tiga kali diletuskan, senapan di tangannya tidak berbunyi. 
Anehnya, saat tiba di kaki bukit senapan itu meletus ketika ditembakkan.

Karakter yang dipahlawankan dalam Legenda mitologis masyarakat lainnya adalah sosok cakal (cikal) wakal, tindhih ukir, atau babat alas. Cakal wakal adalah wong sing wiwiti gawe padesan utawa negara atau wong sing nurunake (leluwur) 'orang yang pertama kali membuka desa' atau 'orang yang mewariskan' (Bausastra Jawa, 2001:88). Tindhih ukir berasal dari kata tindhih/tindhik (bolongan godhoh 'lubang di daun telinga' (Bausastra Jawa, 2001:788) dan ukir/wukir (gunung), yang secara bebas dapat ditafsirkan menjadi 'penanda lahir untuk tempat tinggal'. Babad alas dalam Bausastra Jawa (2001:36) berarti mbukak alas kanggo mbangun padesan 'membuka hutan untuk membangun sebuah desa'. Para cakal bakal, tindhih ukir, atau babad alas yang dimaksudkan antara lain adalah Mbah Denin, Mbah Salam, dan Mbah Dinah (tindhih ukir Dusun Gunung Malang); (Ka)Kek Sujak, Kek Saminah, Kek Rat, Kek Rasmo, Kek Nari, Kek Ban, dan Kek Pun (babad alas Dukuh Tambak Watu); dan Mbah Puger, Sadengel, dan Sagoplo (cakal bakal Dukuh Sumur Ampelsari).

Cakal Bakal Dusun Gunung Malang adalah Mbah Denin, Mbah Salam, dan Mbah Dinah. Mereka berasal dari Pati Jawa Tengah. Kisah ini terjadi pada zaman Belanda, saat Kabupaten Pasuruan dipimpin oleh Bupati Sosronegoro. Mereka menjalankan lelaku untuk memperoleh keselamatan hidup (dalam versi yang lain, Mereka memperoleh wisik 'ilham' agar melakukan perjalanan ke Lereng Arjuna). Untuk mempertahankan hidup, mereka membuka lahan untuk dijadikan tempat tinggal. Karena tidak tersedia air di tempat tersebut, mereka bertapa untuk nyeyuwun sumber mata air. Kebetulan tempat mereka bertapa tersebut tepat di bahwa pohon wangkal yang doyong 'miring'. Maka dari itulah, tempat tersebut disebut wangkal doyong.

Akhirnya, melalui laku ritual tersebut ditemukanlah dua buah sungai kecil, yang berada di atas disebut kali duwur 'sungai atas', sedangkan yang di bagian bawah disebut kali isor 'sungai bawah'. Sungai bagian atas selanjutnya diberi nama Sumber Petung karena di sekitar sungai tersebut banyak ditumbui pohon bambu jenis petung. Sungai di bagian bawah dinamai Sumber Klincir (dalam versi yang lain, Kali Isor atau Sumber Klincir ditemukan melalui kekuatan magis Mbah Denin. Dengan menancapkan tongkatnya ke dalam tanah, keluarlah mata air atau sumber yang kini dikenal sebagai Sumber Klincir).

Melalui laku ritual bertapa tersebut, Buyut Denin dan kedua anaknya juga mengetahui bahwa Sumber Petung atau Kali Nduwur dikuasai oleh Kyai Nolo Gareng dan Sumber Klincir atau Kali Isor dikuasai oleh Nyai Nolo Gareng. (Legenda Wangkal Doyong/Gunung Malang)

Dikisahkan ada tujuh orang pendatang yang mendirikan gubuk di boro (bero) 'lahan yang sengaja tidak ditanami untuk mengembalikan kesuburannya' di tengah perjalanan menuju Lereng Arjuna, tepatnya di daerah Tampuono. Tujuan mereka ke Tampuono untuk lelampan' laku ritual'. Mereka bertujuh adalah (Ka)Kek Sujak, Kek Saminah, Kek Rat, Kek Rasmo, Kek Nari, Kek Ban, dan Kek Pun. Karena merasa haus, mereka bertujuh membatin "Mbok Sing Kuasa maringi banyu”, 'Semoga Yang Kuasa memberi air'. Selepas berujar dalam hati tersebut, tiba-tiba muncul mata air. "Wah, ana banyu, kate dadi kampung daerah iki", 'Wah, muncul sumber mata air, tempat ini akan menjadi kampung'. (Legenda Tambak Watu).

Cakal bakal Desa Sumur Ampelsari adalah Mbah Puger yang mempunyai putra bernama Sadengel dan Sagoplo. Disebut Desa Sumur karena di daerah tersebut terdapat sumur gemuling 'berguling'. Dikisahkan, ada seorang wali (diyakini oleh masyarakat sebagai Mbah Dengel atau Sadengel, putra Mbah Puger) yang akan bersembahyang. Sebelumnya, sang wali hendak mengambil air wudu dari dalam sebuah sumur. Karena tidak ada gayung, sang wali, dengan karomah kewaliannya mengambil air dalam sumur dengan cara memiringkan sumur sehingga air tumpahannya dapat dijadikan air wudhu. Sebelumnya, tongkat sang wali yang berasal dari bambu ngampel ditancapkan terlebih dahulu di atas tanah sebelum berwudu. Sumur gemuling dan tongkat sang wali yang terbuat dari bambu Ampel menjadi ihwal penamaan tempat tersebut, yakni Sumur Ampelsari (Legenda Sumur Ampelsari).

Para cakal bakal desa-desa Lereng Gunung Arjuna, sebagaimana cakal bakal (desa-desa) pulau Jawa pada umumnya, adalah sosok terpilih, sakral, 
dan memiliki kekuatan supranatural. Karena "keunggulan" inilah, mereka menjadi sosok besar dengan potensi-potensi kepahlawanannya. Sebagai sosok terpilih, mereka menjadi alamat wisik gaib dan sasaran bagi tugas-tugas mulia dan luhur. "Mereka memperoleh wisik (ilham) agar mereka melakukan perjalanan ke Lereng Arjuna".

Sebagai sosok suci, mereka identik dengan laku sakral. "Mereka bertiga menjalankan lelaku untuk memperoleh keselamatan hidup. Karena tidak tersedia air di tempat tersebut, mereka bertapa untuk nyuwun (meminta) sumber mata air."

Sebagai sosok yang sakti, mereka dapat menciptakan keajaiban-keajaiban, "Mbah Denin menancapkan tongkatnya ke dalam tanah sehingga keluarlah mata air atau sumber yang kini dikenal sebagai Sumber Klincir. Mbah Dengel mengambil air dalam sumur dengan cara memiringkannya sehingga air tumpahannya dapat dijadikan air wudu.

Durkheim (2011:365) menjelaskan bahwa kemampuan yang melebihi kemampuan manusia biasa menjadi karakteristik leluhur. Bahkan, keinginan dalam hati pun (mbatin) dapat terwujud, "Selepas berujar dalam hati, tiba-tiba muncul mata air." Tentunya, ungkapan-ungkapan verbal para leluhur ini juga memiliki kemujaraban (mandi). "Wah, ana banyu, kate dadi kampung daerah iki", 'Wah, muncul sumber mata air, tempat ini akan menjadi kampung'.

Beatty (2001:63) menyebutkan bahwa di antara sejumlah kata dalam bahasa Jawa mengenai kekuasaan, satu yang secara khusus merujuk kepada pengungkapan verbal yang kuat adalah mandi.

Sosok besar dan legendaris para bedah kerawang desa hingga kini masih mendapat tempat yang istimewa dalam kehidupan masyarakat Lereng Arjuna. Nama-nama mereka senantiasa disebut dalam setiap gelaran hajatan, khususnya dalam ujub selamatan, "Ingkang kula kaweruhi malih cikal wakal trindih ukir bedah krawang ingkang dusun ... ngriki". Tempat-tempat yang diyakini sebagai makam mereka, tidak hanya dipelihara, tetapi juga menjadi tempat ziarah wajib. Dalam kesempatan tertentu, saat masyarakat setempat akan menggelar hajat, makammakam leluhur/nenek moyang ini kerap didatangi, dimintai restu, dan diberi sesaji. Keagamaan orangorang desa ditentukan oleh kepercayaan terhadap eksistensi jiwa manusia yang sesudah kematiannya tetap tinggal di dekat desa dan tetap memerhatikan kehidupannya. Penghormatan terhadap nenek moyang mempunyai kedudukan penting dalam kehidupan keagamaan di desa (Suseno, 1993:38).

Semar, dan para cikal bakal desa adalah sosok "berbobot" yang heroik bagi masyarakat Lereng Arjuna. Karakter manusia pilihan dengan kesaktian yang diperoleh melalui konsistensi laku menjadi alat pengingat masyarakat. Memorisasi dengan memanfaatkan peran noetik (proses-proses mental) dari sosok-sosok "berbobot" yang heroik seperti ini lazim digunakan oleh masyarakat dengan latar kelisanan untuk melestarikan nilai-nilai. Masyarakat (yang dibesarkan dalam kultur) kelisanan (termasuk sebagian masyarakat Lereng Arjuna) menyimpan pengalaman melalui memorisasi karakter-karakter yang "berbobot". Mengingat karakter berbobot yang heroik dengan proses-proses mentalnya (noetik) dapat memudahkan pengorganisasian pengalaman ke dalam bentuk yang mudah diingat secara permanen (Ong, 2002:68-69).

Narasi apokaliptik secara ketat dan runtut sebagaimana tersyarat dalam karakteriktik sastra apokaliptik Leon Harris, memang belum tampak dalam legenda dan mitos masyarakat Lereng Arjuna sebagaimana dideskripsikan di atas. Namun demikian, pengangkatan tema lingkungan dan pengakuan atas keajaiban alam di dalam sastra lisan masyarakat Lereng Arjuna dapat dijadikan dasar untuk mengatakan bahwa sastra lisan masyarakat Lereng Arjuna adalah teks sastra "kesadaran lingkungan". Janik mengklaim bahwa karya-karya Lawrence telah melihat manusia sebagai bagian dari alam semesta organik, hidup terbaik dengan mengakui keajaibannya dan menolak godaan untuk memaksakan kehendak atasnya. Dalam pengertian ini, Lawrence telah berdiri di awal tradisi posthumanis modern dan dari sastra "kesadaran lingkungan" (1995: 107).

\subsubsection{Lingkungan Apokaliptik}

Interpretasi baru tentang apokaliptik sebagai sebuah gagasan yang tidak bertujuan memprediksi masa depan tetapi mengubahnya, diungkapkan oleh Killingsworth dan Palmer dalam catatannya terhadap The Population Bomb karya Paul Ehrlich. Klaim ini 
didukung oleh komentar Ehrlich sendiri (1996:52) bahwa lingkungan apokaliptisisme dalam pemahaman ini bukan tentang mengantisipasi akhir dunia, melainkan upaya untuk mencegah hal itu dengan cara persuasif.

Dalam sastra lisan masyarakat Lereng Arjuna, mereka memulihkan stabilitas alam melalui tindakan pencegahan yang persuasif. Hal ini tampak jelas dalam mantra-mantra berikut.

\section{Mantra menjinakkan angin besar \\ Semillairohmanirohim \\ Raja Ababil kang teka wetan mbalio wetan, \\ Raja Ababil kang teka kidul mbalio mengidol, \\ Raja Ababil kang teka ngulon mbalio ngulon, \\ Raja Ababil kang teka lor mablio ngalor \\ aja sira ganggu gawe anak cucu adam \\ Raja ababil}

Terjemahan

Bismilahirahmanirahim

Raja Ababil yang dari timur kembalilah ke timur

Raja Ababil yang dari selatan kembalilah ke selatan

Raja ababil yang dari barat kembalilah ke barat

Raja Ababil yang dari utara kembalilah ke utara

Janganlah engkau mengganggu hajat anak cucu Adam

Raja Ababil

\section{Mantra Menjinakkan Kilat dan Guntur}

Semilairahmanirahim

Kebyar Wetan, Kebyar Kidul,

Kebyar Kulon, Kebyar Lor

Aja sira ganggu gawe anak cucu Adam

Anak cucu Adam njaluk slamet

Terjemahan

Bismilahirahmanirahim

Kebyar Timur, Kebyar selatan

Kebyar barat, Kebyar utara

Janganlah engkau mengganggu hajat anak cucu Adam

Anak cucu Adam mengharapkan keselamatan

Mantra Menjinakkan Badai

Semillahirohmanirohim

Kaki Braja Nini Braja

Braja kang teka wetan aja sira ngulon,

Braja kang teka kidul aja sira ngalor

Braja kang teka Kulon aja sirangetan

Braja kang teka Lor aja sira ngidul

Teteplanggeng rahayu slamet

Terjemahan

Bismilahirahmanirahim

Kakek Braja (raja) Nenek Braja

Braja yang datang dari timur janganlah kau ke barat
Braja yang datang dari selatan janganlah kau ke utara

Braja yang datang dari barat janganlah kau ke timur

Braja yang datang dari utara janganlah kau ke selatan

Tetap abadi sejahtera selamat

Bencana alam yang diakibatkan oleh hujan dengan intensitas tinggi, angin puting beliung, dan badai yang berpotensi merusak dan menghancurkan kehidupan tergambar jelas dalam latar mantra. Dalam perspektif apokaliptik awal, hal ini adalah sebuah visi Tuhan yang membawa ke kehancuran dahsyat untuk membangun situasi yang lebih baik. Kondisi alam yang berpotensi membawa kerusakan lingkungan ini diantisipasi secara mistis melalui rapalan mantra. Rapalan mantra ini dimaknai sebagai upaya mengharmoniskan kembali hubungan manusia dengan alam. Masyarakat percaya bahwa bencana dan musibah merupakan bentuk kemarahan alam mistis akibat terganggunya kesinambungan hubungan antara manusia dan alam. Suseno (1993:87-89) mengungkapkan bahwa sifat gaib alam menyatakan diri melalui kekuatan-kekuatan yang tidak kelihatan dan dipersonifikasikan sebagai roh-roh. Semua kekuatan alam dikembalikan kepada roh-roh dan keuatan-kekuatan halus. Sakit dan celaka dianggap disebabkan oleh roh-roh itu, begitu pula sukses dan bahagia. Mereka bisa memberikan berkah, tetapi sering pula mereka merugikan.

Lebih lanjut, Suseno menuturkan bahwa kepercayaan terhadap roh-roh juga mempunyai fungsi integratif. Hal ini disebabkan orang Jawa menghubungkan kekuatan-kekuatan alam yang beraneka ragam dengan roh-roh. Karena dapat menamakannya, kekuatan itu tidak lagi anonim, melainkan ditempatkan dalam suatu kerangka yang dapat dimengerti. Bahkan, sampai taraf tertentu dapat dimanipulasikan. Dalam contoh mantra di atas, kekuatan alam yang berwujud angin, petir, dan badai menjadi tidak anonim dengan adanya nama Kaki Braja Nini Braja, Kebyar Kulon, dan Raja Ababil.

Orang Jawa mengalami dunia sebagai tempat yang di dalamnya kesejahteraan bergantung kepada keberhasilan dalam menyesuaikan diri dengan kekuatan-kekuatan (supra)alam, bukan mencegah, apalagi mengubah kekuatan-kekuatan tersebut. Usaha untuk mengubah dunia menjadi tidak mempunyai arti karena kekuatan-kekuatan yang sebenarnya bekerja dalam dunia tidak bersifat empiris sehingga tidak 
dapat kita kontrol. Dunia adalah kerangka kegiatan manusia yang sudah ditentukan. Yang dituntut kepada manusia bukan mengubah dunia, melainkan menjaga keselarasannya. Perilaku manusia untuk mengubah dunia pasti menimbulkan ketidakselarasan alam (simak Suseno, 1993:147-149; Pranoto, 2007:52). Mulder (1978: 38) juga menekankan bahwa dorongan untuk memperbaiki dunia tidak memiliki fungsi penting dalam etika Jawa. Kewajiban manusia terhadap dunia ialah tidak mengganggu keselarasannya. Hal ini dapat terlaksana dengan memenuhi kewajiban-kewajiban pangkatnya.

Harmoni, selain sebagai tujuan perapalan mantra juga dijumpai dalam wujud ekspresinya. Penggunaan frasa baku, yaitu frasa dengan pola tetap, berulang, dan berirama yang kental dalam formula mantra di atas menyajikan kesan keteraturan. Demikian pula penggunaan julukan-julukan seperti Kaki Braja Nini Braja, Kebyar Kulon, dan Raja Ababil yang metonimi-eufemistik dan taklangsung, bertujuan untuk mendudukkan roh penguasa unsur bumi dalam posisi yang terhormat dan terpuji. Tindakan ini merupakan perilaku harmoni. Selain itu, aspek keteraturan juga dapat diamati dalam penggunaan ekspresi redundan, yakni ungkapan yang berulangulang (copio) pada larik-larik mantra.

Gagasan keserasian dan keseimbangan kehidupan manusia dan alam terlahir dari pemikiran bahwa manusia merupakan bagian tak terpisahkan dengan alam. Pemikiran semacam ini merupakan bentuk praktik ekologi dalam. Dalam pandangan masyarakat Jawa, ketakterpisahan manusia dan alam terartikulasi dalam ajaran kosmis memayu hayuning bawana 'mempercantik dunia yang sudah cantik' melalui perilaku kosmis manusia dengan alam gegayutaning manungsa karo alam 'hubungan antara manusia dengan alam'. Menjalin hubungan timbal balik secara baik dengan alam merefleksikan hubungan baik manusia dengan sesama manusia 'gegayutaning manungsa karo manungsa', sekaligus mencerminkan rasa hormat kita terhadap Tuhan 'gegayutaning manungsa karo Gusti kang Murbeng dumadi ingkang akarya jagad (Pranowo, 2007: 69-70).

Secara fisik, apokaliptik ditandai oleh sebuah krisis, keadaan dunia yang berubah, keadaan alam yang memburuk, atau keadaan lingkungan yang tidak dapat dipulihkan (bandingkan Thompson, 2007:13-
14; Garrard, 2004:106). Kondisi seperti ini tergambar dalam Legenda Tambakwatu dan Mitos Patung Betara Guru,

Karena sumber air yang muncul semakin membesar, untuk menampungnya mereka membuat tambak. Seusai tambak jadi dibuat dan sebelum sempat dimanfaatkan, penampungan sumber mata air itu dibuat mandi oleh orang yang tengah mengalami menstruasi. Akibatnya, tambak tempat penampungan sumber air yang belum sempat digunakan tersebut surut dan menyisakan bebatuan saja. Dari sinilah awal penamaan desa Tambak Watu (Legenda Tambakwatu).

Dahulu patung Betara Guru hilang dari tempat asalnya, di Tampuono. Isyarat hilangnya Patung tersebut dirasakan oleh tetua Desa Tambak Watu. Hujan yang tidak kunjung berhenti selama tujuh hari tujuh malam menjadikan Kepala Desa Tompo Rejo khawatir. Ia kemudian meminta Mbah Jountuk melihat ke atas gunung Arjuna (Mitos Patung Betara Guru).

Dalam mitos Patung Betara Guru, perubahan lingkungan dalam bentuk cuaca yang ekstem merupakan sebuah isyarat, pertanda, sasmita alam. Isyarat bahwa telah terjadi ketidakberesan yang mengakibatkan ketidakseimbangan alam. Ketidakberesan yang berakibat pada keadaan inharmoni alam disebabkan oleh adanya desakralisasi mitos oleh profanansi tindakan manusia. Patung Betara Guru beserta mitos dan kepercayaan yang melatarinya merupakan representasi yang mengekspresikan hal-hal yang sakral. Pada sisi lain, pencurian atau pengambilalihan kepemilikan untuk kepentingan pribadi merupakan perilaku sekuler yang profan.

Kehidupan sakral dan kehidupan profan tidak bisa berada dalam ruang yang sama. dunia yang sakral adalah dunia yang terpisah. Karena dunia sakral dipertentangkan dengan dunia profan dengan segala sifatnya, dunia sakral ini harus diperlakukan dengan laku-laku tertentu. Jika dalam proses melakukan kontak dengan sesuatu yang ada kesakralannya (patung Betara Guru) yang digunakan adalah laku, bahasa, dan sikap yang juga kita pergunakan ketika kita hidup di dalam dunia profan (mencuri), hal tersebut berarti telah mengingkari hakikat dunia yang sakral dan mencampuradukkannya dengan dunia yang tidak sakral (Durkeim, 2011:459). 
Kecermatan dan kesigapan sesepuh masyarakat Desa Tambakwatu dalam merespon ketidakberesan di puncak Gunung Arjuna merupakan langkah yang penting bagi pemulihan hubungan dengan lingkungan Gunung Arjuna yang sekaligus merupakan pencegahan terhadap malapetaka yang lebih besar lagi. Selanjutnya, pemindahan dan pembangunan situs patung Betara Guru ke pemukiman desa Tambakwatu (setelah patung tersebut ditemukan) adalah keputusan yang baik untuk keamanan benda suci tersebut, lebih-lebih untuk stabilitas dan pengembangan kehidupan religius masyarakat. Durkheim (2011:446) menuturkan jika kehidupan religius ingin dikembangkan, yang harus dipersiapkan adalah ruangan yang khusus untuknya, ruang yang tidak dapat dimasuki dan disentuh oleh kehidupan profan dan institusi kuil sehingga tempat-tempat suci muncul dari penalaran seperti ini. Tempat-tempat ini merupakan tempat yang diperuntukkan bagi segala hal yang sakral dan dianggap sebagai tempatnya bersemayam.

Kekuatan-kekuatan religius ada dua macam, yaitu kekuatan yang membawa kebaikan dan kekuatan yang dapat mendatangkan kehancuran. Kekuatan yang membawa kebaikan biasanya dapat menjaga tatanan fisikal dan moral, memberi kehidupan, dan kesejahteraan. Mereka ini adalah makhluk-makhluk sakral. Begitu juga dengan tempat-tempat yang dikeramatkan sebagai tempat pemujaan dan objekobjek yang dipergunakan dalam ritus. Di lain pihak, ada pula kekuatan jahat dan tidak suci, pembawa kehancuran, penyebab kematian dan penyakit, kekuatan yang selalu melanggar. Perasaan yang dirasakan manusia terhadap kekuatan-kekuatan ini adalah ketakutan yang biasanya mengandung horor dan teror, seperti kekuatan yang terdapat dalam tubuh mayat dan darah haid, kekuatan yang menyebabkan kesucian menjadi terprofanasi (Durkheim, 2011:585). Kekuatan religius yang membawa kebaikan direpresentasikan mitos Sanggar Pamujan Betara Guru, sedangkan kekuatan penyebab kehancuran dalam Legenda Tambakwatu direpresentasikan oleh darah haid. Kekuatan inilah yang mengakibatkan apokalip lingkungan dukuh Tambakwatu.

Retorika apokaliptik dan tema tentang lingkungan telah hadir secara tersirat maupun tersurat dalam teks mitos dan legenda masyarakat Lereng Arjuna. Sebuah teks yang didasari dan terlahir oleh pemikiran ekologi dalam, layak disebut "teks kesadaran lingkungan". Dalam komentarnya terhadap karya D.H. Lawrence, Del Ivan Janik (1995:107) mengungkapkan bahwa karya sastra dengan tema lingkungan dan retorika apokaliptik yang di dalamnya menggunakan praktik tertentu di dalam deep ekologi-melihat manusia sebagai bagian dari alam semesta organik yang hidup terbaik dengan mengakui keajaiban dan menolak godaan untuk memaksakan kehendak atasnyaadalah sastra "kesadaran lingkungan".

\subsubsection{Visi atau Ramalan}

Informasi tentang apokaliptik sering dikomunikasikan melalui visi atau ramalan. Visi sering menggunakan simbolisme yang aneh, bahkan penuh teka-teki. Visi atau ramalan tentang kemungkinan yang mengancam kehidupan masyarakat Lereng Arjuna dapat dilihat dalam mitos Betara Guru dan mitos Mata Air Gumandar berikut ini.

Dahulu patung Betara Guru hilang dari tempat asalnya, di Tampuono. Isyarat hilangnya Patung tersebut dirasakan oleh tetua Desa Tambak Watu. Hujan yang tak kunjung berhenti selama tujuh hari tujuh malam menjadikan Kepala Desa Tompo Rejo khawatir. Ia kemudian meminta Mbah Jountuk melihat ke atas Gunung Arjuna. Ternyata patung tersebut telah lenyap dicuri orang. Upaya pencarian pun dimulai (Mitos Patung Betara Guru).

Gumandar adalah sumber mata air yang jaraknya $12 \mathrm{~km}$ dari Desa Tambak Sari. Air dari sumber ini pernah akan dialirkan masyarakat Nggamoh dan Cowek ke desanya. Namun, karena panjalukan 'permintaan' 'penunggunya' terlalu berat sehingga mata air tidak jadi dialirkan. Masyarakat Nggamoh tidak sanggup karena Danyang Sumber Gumandar minta persyaratan agar disediakan dawet mata sebelanga. Sementara itu, masyarakat Cowek tidak sanggup karena sesepuh desa mendapati pertanda buruk karena Danyang meminta ayam anggrem 'mengeram' sejumlah 20 ekor. Mendengar informasi bahwa mata air belum ada yang memanfaatkan, Pak Tina bersama, Pak Carik, Pak Turawi (ulu-ulu banyu), dan Pak Taman berangkat ke Sumber untuk nyuwun sumber Gumandar. Setelah tiga kali suguh, yakni setelah magrib, jam 24.00, dan jam 03.00, didapatkan wisik oleh Mbah Tinanton (waktu itu bayan), 
Aku gelem didhunna nang Tambak Watu, sarate nyaluk papakan reman ludruk.

'Aku mau diturunkan ke Tambakwatu, syaratnya aku minta jemputan remo ludruk.'

Setelah mendapatkan restu, masyarakat mengumpulkan Deling (bambu) untuk pipa alirnya. Waktu itu bambu satu kampung habis digunakan, bahkan masyarakat harus mencari tambah hingga ke desa tetangga untuk mengalirkan air sejauh $12 \mathrm{~km}$. Setelah air mengalir, Pak Tinaton dan warga menggelar pertunjukan ludruk sebagai papakan (Mitos Mata Air Gumandar).

Hujan tanpa henti selama tujuh hari tujuh malam (Mitos Patung Betara Guru) dan permintaan dawet sebelanga serta permintaan ayam anggrem sejumlah 20 ekor (Mitos Mata Air Gumandar) merupakan visi yang menuntut pemaknaan dan penafsiran. Visi dalam teks di atas disampaikan melalui manusia terpilih yang dalam hal ini adalah sesepuh desa yang sebelumnya telah menjalankan laku ritual khusus, misalnya puasa makan, puasa tidur (melekan), atau bersemedi.

Berdasarkan laku ritual tersebut, disimpulkan kemungkinan buruk yang akan terjadi pada masa depan, misalnya hujan tiada henti selama tujuh hari tujuh malam dan akan berakibat pada banjir dahsyat jika tidak segera menemukan sebab dan mencari solusi secepatnya. Demikian pula dengan permintaan dawet mata sebelanga dan ayam anggrem sejumlah 20 ekor yang ditafsirkan sesepuh desa sebagai tumbal manusia. Permintaan ayam anggrem sejumlah 20 ekor diyakini sebagai perlambang (simbol) ibu yang tengah mengandung. Jika aktivitas dilanjutkan, akan banyak ibu-ibu yang meninggal saat melahirkan.

Visi akan berakhir dengan bencana dahsyat yang menyebabkan kehancuran kehidupan jika manusia menurutkan hawa nafsu sehingga memaksakan kehendak atas alam. Sebaliknya, apokalip lingkungan dapat dicegah melalui upaya komunikasi dan kompromi dengan alam. Upaya tersebut tampak dalam laku ritual nyuwun yang dilakukan sesepuh
Nggamoh, Cowek, dan Tambak Watu. Nyeyuwun atau nuwun yang berarti 'tetembungan sing mratelakake (aweh weruh marang) pakurmatan 'ungkapan yang menyatakan penghormatan' dilakukan masyarakat untuk membina hubungan baik.

Upaya kompromi juga ditunjukkan dalam sikap masyarakat Nggamoh dan Cowek yang mengurungkan niat untuk mengambil air. Berikutnya, digelarnya pertunjukan ludruk setelah air sumber mengaliri Dukuh Tambak Watu juga merupakan bentuk komunikasi dan kompromi masyarakat dengan kekuatan alam. Pada akhirnya, apokaliptik dapat dicegah dengan cara-cara persuasif. Lingkungan apokaliptisisme tidak berbicara tentang mengantisipasi akhir dunia, melainkan upaya untuk mencegah akhir dunia dengan cara-cara persuasif (Garrard, 2004:99).

\section{PENUTUP}

Gagasan apokaliptik dalam teks sastra lisan masyarakat Lereng Arjuna tersimpan di balik latar penamaan desa, latar penamaan situs-situs purbakala dan situs keramat alami, serta penamaan para baureksa dalam mantra. Penamaan tersebut diangkat atau terinspirasi dari penggalan, kutipan, atau sebagian kisah pewayangan, suluk, dan kitab suci. Gagasan ini juga terungkap sebagai cara pemulihan stabilitas alam melalui tindakan pencegahan yang persuasif (melalui pemujaan mantra, laku ritual), bukan mengubah masa depan alam. Gejala apokaliptik yang tergambar dalam sastra lisan Lereng Arjuna merupakan isyarat, pertanda, sasmita bahwa telah terjadi ketidakberesan yang mengakibatkan ketidakseimbangan alam. Selanjutnya, visi dalam sastra lisan Lereng Arjuna disampaikan melalui sesepuh desa yang sebelumnya telah menjalankan laku ritual khusus. Dari laku ritual tersebut disimpulkan kemungkinan buruk yang akan terjadi pada masa depan.

\section{DAFTAR PUSTAKA}

Anwar, Khairil. 2011. Pembelajaran Sastra Lisan: Upaya Pelestarian Mutiara yang Terlupakan. Makalah disajikan dalam Seminar Internasional Pemikiran-Pemikiran Inovatif dalam Kajian Bahasa, Sastra, Seni, dan Pembelajarannya, FPBS UPI, Bandung, 30 November.

Beatty, Andrew. 2001. Variasi Agama di Jawa: Suatu Pendekatan Antropologi. Jakarta: Raja Grafindo Persada. 
Sony Sukmawan : Apokaliptisme Sastra Lisan Lereng Arjuna

Butterfield, Deborah St. Goerge. 2009. "Toccata and Fugue: The Hegemony of the Eye/I andthe Wisdom of the Ear," dalam The Trumpeter, Vol. 10, No. 3, hlm. 106-111.

Carter, John W. 2010. “An Introduction to the Interpretation of Apocalyptic Literature,” dalam The Journal of Ecocritism. Vol. 2, No. 2. (Online), (http://ojs.unbc.ca/index.php/joe/article/view/129), diakses 2 Juli 2012.

Danandjaya, James. 2002. Folklor Indonesia. Jakarta: Pustaka Utama Grafiti.

Dundes, Alan (ed.). 1965. The Study of Folklore. Englewood Cliff: Prentice Hall Inc.

Durkheim, Emile. 1979. "The Elementary Form of The Religious Life," dalam Williem A. Lessa dan Evon Z. Vogt, (ed). Reader in Comparative Religion: An Antropological Approach. New York: Harper and Row Publiser.

Ehrlich, P. 1998. Betrayal of Science and Reason: How Anti-Enviromental Rhetoric Threatens Our Future. Washington D.C.: Island

Endraswara, Suwardi. 2010. Folklor Jawa: Bentuk, Macam, dan Nilainya. Jakarta: Penaku.

Finnegan, Ruth. 1992. Oral Traditions and The Verbal Arts: A Guide to Research Practices. London and New York: Routledge.

Garrard, Greg. 2004. Ecocriticism. New York: Routledge

Glothfelty, C. dan H. Froom (eds.). 1996. The Ecocriticism Reader: Landmarks in Literary Ecology. London: University of Goergia Press.

Janik. Del Ivan. 1995. "Environmental Consciousness in Modern Literature: Four Representative Examples," dalam G. Sessions (ed.), Deep Ecology for the Twenty-First Century: Reading on the Philosophy and Practice of the New Environmentalism. London: Shambhala.

Kerridge, R. dan N. Sammells (eds.). 1998. Writing the Environment. London: Zed Books.

Mulder, Niels. 1978. Mysticism and Everyday Life in Contemporery Java: Cultural Persistence and Change. Singapore: Singapore University Press.

Ong, Walter J. 2002. Orality and Literacy: The Technologizing of the Word. New York: Routledge.

Pranoto, Tjaroko H.P. Teguh. 2007. Spiritualitas Kejawen: Ilmu Kasunyatan, Wawasan dan Pemahaman, Penghayatan dan Pengalaman. Yogyakarta: Kuntul Press.

Proop, Vladimir. 1997. Theory and History of Folklore. Minneapolis: University of Minnesota Press.

Semali, Ladislaus M. and Joe L. Kincheloe. 1999. What Is Indigenous Knowledge? Voicesfrom The Academy. New York: Falmer Press.

Spradley, James. 1997. Metode Etnografi, diterjemahkan oleh Misbah Zulfa Elizabet. Yogyakarta: Tiara Wacana Yogya.

Sudikan, Setya Yuwana. 2001. Metode Penelitian Kebudayaan. Surabaya: Citra Wacana.

Suseno, Franz Magnis. 1993. Etika Jawa: Sebuah Analisa Falsafi tentang Kebijaksanaan Hidup Jawa. Jakarta: Gramedia Pustaka Utama.

Sutarto, Ayu. 2009. Mulut Bersambut: Sastra Lisan dan Folklor Lisan sebagai Instrumen Politik pada Era Soekarno dan Soeharto. Jember: Kompyawisda Jatim. 
Sony Sukmawan : Apokaliptisme Sastra Lisan Lereng Arjuna

Teorey, Matthew. 2010. "Ecological Discourse in Craig Childs's The Secret Knowledge of Water," dalam The Journal of Ecocriticism, Vol. 2, No. 2. (Online), (http://ojs.unbc.ca/index.php/joe/article/view/129), diakses 2 Juli 2012.

Thompson, D. 1997. The End of Time: Faith and Fear in the Shadow of the Millenium. London: Minerva.

Tim Penyusun Balai Bahasa Jogjakarta. 2001. Kamus Basa Jawa: Bausastra Jawa. Jakarta: Kanisius.

Triyoga, Lucas Sasongko. 2010. Merapi dan Orang Jawa: Persepsi dan Kepercayaannya. Jakarta: Grasindo. 
Sony Sukmawan : Apokaliptisme Sastra Lisan Lereng Arjuna 